\title{
Mode of Foreign Market Entry: An Analysis of the Property and Liability Insurance Industry
}

\author{
by Frederick W. Schroath*
}

\begin{abstract}
The choice of foreign market entry technique has been identified as a frontier issue in international marketing. New theories of international operations and modes of foreign market entry are emerging in the literature. Yet, little empirical research concerning foreign market entry has been conducted that focuses on service industries. Multinational insurers face a wide array of choices with respect to foreign market entry technique.

This study examines the techniques primary property and liability insurers use to enter foreign markets. Two methodologies are used: structured interviews and questionnaire survey. Results of 21 interviews are reported. Responses to the survey were received from 271 companies domiciled in 47 countries. Data were collected for 216 foreign market entries. Summary statistics are reported and the data are analyzed in the context of foreign market entry theories.
\end{abstract}

\section{Introduction}

The decision to enter a particular foreign market and the choice of entry technique are complex ones for multinational insurers. There are a variety of motivations for entering foreign markets. The extent of participation in the foreign market and the way in which the insurer participates also present a wide array of choices. Each firm making these choices does so in the context of its corporate environment, that is, in light of its company characteristics and its perceptions of the foreign market environment, i.e. the market characteristics.

\footnotetext{
${ }^{*}$ Kent State University, Kent, Ohio, USA.
} 
The interaction of these variables and the impact of particular variables on the ultimate success of the insurer in entering foreign markets is not widely understood or well documented. The literature of international business is rich in the area of foreign direct investment, yet much of this analysis is devoted to manufacturing and extractive industries. Recently scholars have turned their attention to analyzing more precisely the techniques and strategies used to enter foreign markets, but again, this research is largely rooted in the manufacturing segment.

\section{Mode of entry theory}

The choice of an appropriate foreign market entry technique and the process by which the multinational firm makes that choice, have been identified as frontier issues in international marketing [19]. The multinational firm is able to choose from a wide variety of techniques and methods by which it can participate in foreign markets. Each of these techniques offer the firm trade offs, among these are: ease of use, degree of management control, cost, visibility, and speed of entry.

These trade offs are difficult to evaluate, yet "the impact of entry modes on the success of foreign operations is great" [2]. Anderson and Gatignon have proposed a transactions cost framework in which to evaluate these decisions. The focus of this theoretical frame work is control. Control, they assert, "is a way to obtain a higher return... yet control carries a high price" $[2$, p. 3$]$.

Based upon management and economic literature the authors have clustered various entry techniques according to whether or not they are high control modes, medium control modes or low control modes. The choice of entry technique is then derived based upon four constructs. These are:

1. transaction-specific assets: investments (physical and human) that are specialized to one or a few uses,

2. external uncertainty: the unpredictability of the entrant's external environment,

3. internal uncertainty: the entrant's inability to determine its agents' performance by observing output measures,

4. free-riding potential: agents' ability to receive benefits without bearing the associated costs [2, p. 7].

Implicit in this model is that higher control entry modes have higher associated costs.

An examination of international business theories and their application to services was undertaken by Boddewyn, Halbrich and Perry [5]. They found that existing theories such as those advanced by Buckley and Casson, Rugman and Dunning do have application to multinational service firms. These theories also seek to explain the decision to operate internationally within the transaction cost frame work.

In oder for a firm to be induced to enter a foreign market, the firm must have specific ownership advantages (assets or endowments) that exceed the cost of servicing a distant market in an unfamiliar environment and which allows it to compete favorably with the indigenous industry. How the firm uses its ownership specific advantages - that is, whether it sells specific services (e.g. accident and loss control), licences its name (e.g. through a 
managing general agent), or internalizes its firm specific advantage through direct entry into foreign markets - is dependant upon the degree of profitability derived from the use of these assets or endowments in conjunction with the resources available in the foreign market $[9,10)$.

Factor inputs necessary to internalize international operations consist of two types: location specific inputs in the foreign market, (financial infrastructure, market structure, natural resources, etc.) available to all firms entering a particular foreign market and firm specific inputs such as technology, marketing skills and management skills, which the firm itself may create. Dunning extends the internalization concept by linking the origin of firm specific advantages to country of origin. According to Dunning a key characteristic of these firm specific inputs is that:

The ability of enterprises to acquire ownership endowments is clearly not unrelated to the endowments specific to the countries in which they operate and particularly their country of origin. Otherwise, there would be no reason why the structure of foreign production of firms of different nationalities should be different. But, in fact, it is so and substantially so $[9$, p. 10$]$.

Market imperfections and hence high transaction costs arise where information and/or negotiation costs are high or where the economies of interdependent activities cannot be fully captured. The likelihood of internalization of firm specific ownership advantages, and hence direct foreign market entry, is increased where price discrimination is not practiced, where enforcement costs are high for protecting property rights, and where the firm wishes to have a high degree of control over product or service quality. Additionally, the likelihood of internalization of firm specific ownership advantages is increased by the presence of underutilized capacity, especially managerial skills, which the firm can exploit at low marginal cost.

\section{Empirical studies}

Although these theories have been applied to international banking and other services industries [5], they have yet to find application in international insurance operations. In general, there is an absence in the literature of emperical studies of international operations of service firms and international insurance firms in particular. Two studies that did include service firms were conducted by Buckley and Mathew [6,7]. These studies involved a survey of 42 recent entrants to the Australian market. Results were given for 18 distributors of goods manufactured in the UK, 17 firms engaged in manufacturing and 17 firms engaged in providing services. In the services area five firms were merchant bankers, five were in the construction industry, three were engineering firms, three were involved in philatelic sales, insurance broking and personnel placement and one was a supplier of trade services to the printing industry. None were insurance companies.

The results of the two studies are presented by category: distribution, manufacturers and service. The authors pay particular attention to the service sector since "such firms belong to the group which has had least attention in the international business literature $[6$, p. 57]." Concerning motivation, investors were asked why they chose foreign investment 
in preference to domestic (UK) expansion. The results for the services sector are as follows: 15 companies answered "to utilize skills, knowhow and reputation in a market where opportunities are less restricted", one answered "to retain business in Australia" and one answered "to assist growth of UK business [6, p. 61]". There was no breakdown of results within the services category, thus the motivation of the insurance broker could not be determined.

Respondents were also asked questions concerning barriers to entry. As might be expected, the services sector was most concerned with legal barriers. Cultural unity and geocultural distance were generally regarded as unimportant by all of those surveyed. Additionally, the questions concerning motivation were analyzed to determine if the reasons for entry were aggressive or defensive. The results showed that only the services firms stressed market opportunity coupled with the desire to achieve worldwide market coverage. Service firms were also motivated to invest by important UK clients who wish to have the same services in Australia as they are used to in the UK.

Concerning choice of entry technique, the Buckley and Mathew found that consistently companies believe a wholly owned subsidiary will give them easier control, better feedback, higher profits, financial flexibility (particularly the ability to decide whether or not to retain earnings rather than pay dividends) and will require less management discussion and time [7, p. 41].

Additionally, the authors analyzed the preference of firms to take over existing firms in the market or to start a new venture (greenfield ventures).

They found that service firms were more likely to use greenfiled ventures. Among the reasons cited for this choice were: the greater control offered by this technique, the opportunity to introduce desired methods and the fact that the service firms considered that they were providing operating expertise that did not exist in Australia, rather than technical expertise which could be more readily injected into an existing business. They note that

Where a company believes its advantage is its marketing expertise and it does not transfer an experienced executive but instead takes over an existing enterprise, then it is hard to accept that the advantage is being transferred - as occasional visits must be a relatively inefficient method for transferring such expertise [7, p. 47]."

\section{Motivation for insurers to enter foreign markets}

Bickelhaupt and Bar Niv [4] offer some insight into the motivation for insurers to enter international markets. Although the motives given are those of U.S. insurers, they can be generalized to the industry as a whole. These are:

1. Following U.S. businesses to other countries: When insureds expand their operations outside the U.S., they need insurance in foreign countries for both persons and properties. Insurers operating internationally can coordinate the total coverages, including the use of foreign local insurers by those clients.

2. Profits, with high potential in expanding economies: Insurance profitability has often been lower in the U.S. than in other countries. Moreover, U.S. insurers want to explore potentially profitable opportunities in new and expanding markets. 
3. Competition: Many insurers want to compete in international insurance because often it involves larger firms and sizable premiums.

4. Spread of risks: Insurers seek greater diversification of risks, and through geographic dispersion and reinsurance the effects of catastrophic losses are reduced on any one insurer's operations.

5. Challenge and intrigue of foreign operations: The psychological motivations of expanding to new global markets are both exciting and challenging for insurers.

6. Communication and statistical information improvement: Although understanding and evaluating foreign markets is difficult, more rapid and accurate knowledge is becoming available.

7. Prestige and public relations: Operating internationally may create a more competent image and may enhance the reputation of an insurer [4, p. 33].

\section{Mode of foreign market entry}

Bickelhaupt and Bar-Niv describe nine methods by which property and liability insurers can enter foreign markets.

These are:

1. Formation of a branch office or use of an authorized representative.

2. Establishment of a new subsidiary or an affiliated insurer.

3. Acquisition of an existing foreign insurer as subsidiary, or purchasing majority or minority interest in existing foreign insurers.

4. A joint venture between an alien insurer and a domestic insurer, or between an alien insurer and a domestic corporation not principally engaged in insurance. Where it is an insurer, the domestic company may serve as a fronting company or the combination may be a control group. The insurance is written by a domestic licensed insurer, but immediately reinsured by an alien nonadmitted insurer.

5. An alien insurer may act as a nonadmitted insurer. However, only about 20 countries, including the U.S. recognize nonadmitted carriers.

6. Establish a reinsurance company. An insurer from one country may act as an approved reinsurer in another country, recognized by the government in that country, or in some cases the insurer may operate there as a reinsurer without approval.

7. A cooperative agreement for licensing agents between insurers from different countries. This may often be done between a domestic insurer and an insurer from another country. However, sometimes such an agreement is between two or more insurers from different countries for operations in a third country.

8. Arrangement between an alien insurer and a local broker. The broker places the insurance but the alien insurer remains nonadmitted. This practice exists in the excess and surplus-line markets, which involves types or amounts of insurance that are difficult for admitted insurers to write.

9. Providing services, consulting and expertise, especially in risk control and other risk management areas [4, p. 35]. 


\section{Methodology of the research}

\subsection{Research scope and purpose}

The purpose of this research was to investigate the ways in which primary property and liability insurers enter foreign markets and to determine if one technique or mode of entry is ultimately more successful than any other.

\subsection{Hypothesis}

Much of the academic literature has been devoted to enumerating and analyzing barriers to international trade in insurance [3]. The insurance trade literature shows a similar pattern. That trade barriers exist and present formidable obstacles to entering the market in many countries is well documented $[8,13,16]$. Yet, some primary property and liability insurers from Europe, Asia, Latin America and the United States have been able enter and operate with apparent success in many foreign markets.

The literature documents up to nine possible entry techniques an insurer could use to enter a particular foreign market. Only the following techniques, however, require the insurer to make a substantial capital commitment in order to operate in the foreign market.

1. Establishing a new branch office

2. Contracting with a managing general agency

3. Establishing a new (greenfield) subsidiary

4. Purchasing a local national insurer

5. Forming a joint venture.

It is these entry techniques with which this study is principally concerned. The potential succes of each technique depends upon the ability of the company to use that technique and its appropriateness in the marketplace it wishes to enter.

Several heuristic guidelines have been proposed concerning foreign market entry. One author proposed that "the soundest approach for a company is to develop its own producing and underwriting network on a country-by-country basis [12, p. 22]."

Another author has suggested that success in world markets is related to centralizing the international underwriting function and not to any entry technique [17]. Yet another author concludes that the choice of entry technique is highly individualized and depends upon the required size of operations and the quickness of growth required [14].

Despite the prescriptive nature of these statements, none of the authors based their recommendation on empirical research. The intent of this research was to discover if there is a relationship between succes in a particular foreign market and the technique used to enter that market. More specifically, the research sought to test the null hypothesis that given a particular market environment, and a particular set of company characteristics, no foreign market entry technique is more successful than any other.

\subsection{Interviews}

Given the dearth of empirical research in this area a need existed to employ methodologies that covered the topic thoroughly as well as tested the hypothesis. Because of the need for exploratory study and the need for an empirical test, two methodologies were used: structured interviews and questionnaire survey. 
The purpose of the interviews was twofold: to gather background data concerning the process by which companies select and enter foreign markets and to develop appropriate questions for the survey instrument. Interviews with executives from three companies in the United Kingdom, two companies in continental Europe, five companies in the United States, a European trade association and an American trade association were conducted. In all, discussions were held with 21 executives in five countries.

A series of 16 structured questions was asked of each of executive. The questions were designed to elicit general information concerning international operations of primary property and liability companies as well as specific information about each executive's company.

\subsection{Questionnaires}

The answers to the interviews questions formed the basis for a survey questionnaire that was subsequently sent to 423 companies in 63 countries. Ultimately, 271 responses were received from companies in 47 countries. Of these, 80 companies reported entering foreign markets and provided usable data concerning 216 market entries. The questionnaire was given its initial test with the first three United States' companies interviewed. Once refined through these interviews, a subsequent mail out test was conducted.

The questionnaire was divided into three parts to enable any company receiving it to answer some questions. Part one contained questions to be answered by companies that had entered foreign markets. Part two contained questions to be answered by companies that had not yet entered any foreign market but were contemplating doing so. Part three contained questions for companies that did not intend to enter any foreign market.

Companies that had entered foreign markets were asked to provide data concerning the five most recent foreign market entries. These data included:

1. Name of country entered,

2. Year entered,

3. Foreign affiliate name,

4. Motivation for entering each market,

5. Technique used to enter each market and

6. Degree of success in each market entered.

Companies that had entered one or more foreign markets were asked if they had withdrawn from any foreign markets. If they had, the were asked to provide the following information for three of the markets from which they withdrew:

1. Name of the country from which the company withdrew,

2. Year withdrawn,

3. Name of foreign affiliate,

4. Entry technique used to enter the market, and

5. Reason for withdrawal.

These companies were also asked to list up to three countries in which they considering entry, in order of preference and what entry technique they planned to use in each country. 
Companies were asked to list, in order of importance, the economic, political or other criteria they used in deciding whether to enter a particular foreign market. A question concerning control of foreign affiliates was also asked. Respondents were asked to pick a statement that best described the relationship between the parent company home office and the foreign affiliates.

\section{Interview results}

Although executives provided informative answers to all of the interview questions, the most important question for the purpose of this study concerned the potential success of the various modes of foreign market entry. A summary of the interview results concerning the five selected entry modes follows.

\subsection{Joint ventures}

There was general consensus among those interviewed that the formation of a new branch office was preferred because of the degree of control it allowed. One descenter from that view stated that his company would prefer to joint venture where they could retain control and/or majority ownership.

Particularly in the type markets currently being entered by the company (mostly rapidly industrializing countries) the executive felt that this strategy was necessary for three reasons:

1. to build a political base for future operations

2. to minimize risk to his company

3. to have access to local financial intermediaries.

In addition, he noted that in several countries, Kenya for example, it was necessary to joint venture even though it was not legally required. In other countries, Mexico was cited, where it is technically illegal to have management control, partners can be found who are willing to relinquish effective control. According to this executive "we found someone in Mexico, and it wasn't too hard, who was willing to sit back and enjoy the profits and let us run the show".

The major problem in forming a joint venture, all executives agreed, was finding the right partner or partners. As one commented, "finding a partner isn't a problem; we get calls every week or so from someone who wants to work a deal, coming up with the right deal is another matter".

Companies varied in their approach to finding a joint venture partner. Larger companies, even those with little experience in foreign markets, rarely sought joint ventures actively. Instead they preferred to have opportunities offered to them by potential partners. Several companies had compiled lists of countries where they felt entry was desirable or required to serve multinational clients. Opportunities presented in those countries were then given greater attention at higher levels.

The most talked about issue concerning joint ventures was control. Several companies felt that "balance sheet control", to use the term coined by one interviewee, was essential. That is, the company must have a large enough financial interest to control management appointments. Other executives minimized the importance of financial control and instead emphasized "technical" control. 
These executives felt that control over day to day underwriting activities was more important to the success of the venture than general management. One company manager said his company's policy in joint ventures was to provide only technical expertise and little or no capital. As an example he cited his company's joint venture in the Philippines: "As long as we can manage (the company) we'll trade in our name, but we don't want to operate on our money." Another executive said that he felt it essential for success that there be only one individual with the ultimate authority to price and underwrite accounts.

Another issue that arose concerning joint ventures was their ultimate dissolution. Few joint ventures are expected to be permanent. In the words of one manager, "we simply outgrow our partners and, really, we know that when we enter the relationship." The attitude of most managers interviewed was that joint ventures were useful as a means of building a political base and learning the fundamentals of successful operations in a particular foreign market.

In the long run, joint ventures were viewed primarily as a means to an end. In some instances, joint ventures are formed with the knowledge that one of the partners will ultimately purchase the interests of the others, thus gaining direct entry to the foreign market. In other cases the failure to resolve disputes with joint venture partners leads to abandonment of the market entirely.

\subsection{Branches and subsidiaries}

Despite the preference of companies to open new branch offices as a means of entering foreign markets, this technique is not always available to companies and, even where permitted, companies must often convert to subsidiary operations within a relatively short time, typically three to five years. Companies have also received pressure to convert to subsidiaries in countries where this is not legally required.

Consequently, several of those interviewed stated that their companies either entered markets by forming subsidiaries or converting to subsidiaries shortly after entering with a branch. Again, the issue of control was a key in deciding whether or not to enter using subsidiaries. The required amount of local equity participation, if any, was seen as a major factor concerning the decision to use subsidiaries. A second factor was the amount of capital required by the insurance regulatory authority and the laws of incorporation in the foreign market.

Third, was the problem of foreign-exchange rate risk. On this point companies seemed to be divided by company philosophy. One manager stated that it was company policy to avoid exchange risk by localizing capital. A second stated that company policy was to "keep the money at home and only minimally capitalize foreign affiliates except in one or two countries." This philosophy was a result of advantageous foreign exchange regulations and tax laws in the United Kingdom according to this manager. Interestingly, both executives were from U.K. companies. This clearly underscores the impact of company philosophy and company characteristics on choice of entry technique.

Forming a new subsidiary represents a substantial commitment to the foreign market. But, as several executives noted, this commitment may become a marketing advantage for the company, in that its distributors and customers may also recognize it as a commitment to continue in the market. 


\subsection{Managing general agencies}

Companies with greater experience in entering foreign markets are less likely to use managing general agencies to enter a foreign market. Three reasons were given: first, problems with control, second, experienced companies can more easily find alternatives, and third, the cost of using managing general agencies.

Companies who felt that it was necessary to use managing general agencies, less experienced companies and those that felt pressured to enter a particular market quickly, believed that tight control was essential to success. One company that had recently entered the United Kingdom required its managing general agent to send monthly reports and, in turn, sent to the agent revised underwriting guidelines on a monthly basis.

Even with this degree of control the company felt that further steps to tighten control were necessary. The company planned to place one of its executives in the managing general agency to oversee day to day operations. Finally, the company planned to use this arrangement for only two or three years, after which it would enter the market using its own personnel.

Not unlike joint ventures, companies occasionally enter markets using a managing general agent with the intention of purchasing the agency in the future. The consensus of those interviewed, however, was that while managing general agencies may provide speed in entering markets and may be a useful training ground for less experienced companies, those companies serious about foreign markets must ultimately use another form of organization.

\subsection{Purchasing a local national insurer}

While managers generally agreed that purchasing a local national insurer offered the potential advantages of speed in entering the market, locally experienced management and a marketing base, it also presented management with difficult analysis and choices. One of the major obstacles cited was obtaining accurate and comparable financial data.

There appear to be myriad ways in which insurers can report financial information. Regulatory reporting requirements vary from country to country in ways that do not permit easy conversion from one system to another. In some countries, insurers are given choices in reporting certain information so that it may not prove easy to compare one insurer to another even within the same country. Finally, there is the matter of accuracy. Regulatory authorities in many countries do not have the financial wherewithal or expertise to carefully scrutinize the reports of the companies they regulate.

In particular, Italy and Spain were cited as countries where financial reports need to be carefully evaluated, as were a number of Latin American countries. In these countries companies are permitted to operate with much lower solvency margins and hence may represent higher risk ventures.

Companies differed in the way they sought takeover targets in foreign markets. Several executives said they did not actively seek opportunities to purchase companies in foreign markets but instead waited until they were offered the right opportunity. Other executives said that in targeted foreign markets they "put out the word" and actively try to find companies that might be available. Queried about sources of information, several said that their multinational clients often proved to be their best source. Another source of information on possible take-over candidates cited was the insurer's public accounting firm. 
Managing the acquisition of the local national insurer also requires considerable management attention. If the acquiring company moves too fast to install its management and marketing philosophy it may loose the very asset several executives felt was most valuable: management of the local firm. Although here too there was some difference of opinion that seemed to be reflected in company philosophy.

Several managers said they would not consider buying a local national insurer unless it was already well managed. At least two other executives stated that they preferred takeover candidates in need of rehabilitation simply because it allowed them to more quickly inject their own management team. Asked to sum up the decision making process concerning acquisition in his firm, one executive said, "it seems to me mostly to be a matter of whether the stars stand in the right position... then the managing board says go."

\section{Questionnaire results}

The most frequently entered country was the United Kingdom with 27 entries. Second was the United States with 18 entries. Table 1 displays the most frequently entered countries. These 17 countries accounted for 156 market entries or 72 percent of the sample.

Table 1: Most frequently entered countries

\begin{tabular}{lr} 
Country & Number of \\
\hline & \\
United Kingdom & 27 \\
United States & 18 \\
France & 15 \\
Belgium & 14 \\
Italy & 10 \\
& \\
The Netherlands & 9 \\
Canada & 9 \\
West Germany & 9 \\
Spain & 8 \\
Australia & 5 \\
Hong Kong & \\
Greece & 5 \\
Switzerland & 5 \\
Saudi Arabia & 4 \\
Singapore & 4 \\
& 4 \\
Portugal & \\
Japan & 4
\end{tabular}

The motivation for entering foreign markets is given in Table 2. Multiple responses were received to this question which accounts for the total being greater that 216 . Among the 17 who responded by providing other reasons for entering foreign markets, three 
reasons predominated: (1) seeking an investment in a country with a stable currency and economy, (2) seeking an investment in a country with a stable political system and (3) seeking education and experience in an insurance market that is more technically advanced.

Table 2: Motivation for foreign market entry

\begin{tabular}{lcc} 
Reason & Number of responses & Percent \\
\hline $\begin{array}{l}\text { Seeking greater growth abroad } \\
\text { Following multinational clients }\end{array}$ & 78 & 26.80 \\
$\begin{array}{l}\text { Spread of risk through } \\
\text { geographic diversification }\end{array}$ & 72 & 24.75 \\
$\begin{array}{l}\text { Seeking greater underwriting } \\
\text { profits abroad }\end{array}$ & 72 & 24.75 \\
Other (please specify) & 52 & 17.86 \\
\hline Total & 17 & 05.84 \\
\hline
\end{tabular}

The use of various modes of entry is given by Table 3. A review of the 13 responses checked "other" reveals that 7 companies accounted for the 13 responses. Eight responses out of the 13 involved reciprocal reinsurance operations or "fronting." In five other responses, the companies indicated that they had purchased a minority share in a foreign company. Table 4 displays the success in using each of the entry techniques while Table 5 shows the success in entering various foreign markets. Using a scale of 1 to 10 , respondents were instructed that 1 represented the least success while 10 represented the greatest success. Of the 17 countries that received four or more market entries. Singapore had the highest average success rate with 8.75 . Switzerland experienced the lowest average success rate with 4.75 .

Table 3: Choice of entry technique

\begin{tabular}{|c|c|c|}
\hline Entry technique & Number of responses & Percent \\
\hline Established a new branch office & 69 & 31.84 \\
\hline $\begin{array}{l}\text { Contracted with a managing } \\
\text { general agency }\end{array}$ & 58 & 26.85 \\
\hline Established a new subsidiary & 28 & 12.96 \\
\hline $\begin{array}{l}\text { Purchased an insurance company in } \\
\text { the foreign country }\end{array}$ & 27 & 12.50 \\
\hline Formed a joint venture & 21 & 09.70 \\
\hline Other (please specify) & 13 & 06.15 \\
\hline Total & 216 & 100.00 \\
\hline
\end{tabular}


Table 4: Mean success by entry technique

\begin{tabular}{|c|c|c|}
\hline Entry technique & $\begin{array}{l}\text { Number of responses } \\
\text { using technique }\end{array}$ & $\begin{array}{l}\text { Mean } \\
\text { success }\end{array}$ \\
\hline Established a new subsidiary & 28 & 6.880 \\
\hline $\begin{array}{l}\text { Purchased an insurance company in } \\
\text { the foreign country }\end{array}$ & 27 & 6.666 \\
\hline Other (please specify) & 13 & 6.375 \\
\hline $\begin{array}{l}\text { Contracted with a managing } \\
\text { general agency }\end{array}$ & 58 & 6.156 \\
\hline Established a new branch office & 69 & 6.052 \\
\hline Formed a joint venture & 21 & 5.687 \\
\hline
\end{tabular}

Table 5: Mean success by market entered

\begin{tabular}{lcc} 
Country & Number of entries & Mean success \\
\hline Singapore & 4 & 8.75 \\
Australia & 5 & 7.40 \\
Italy & 10 & 7.10 \\
United States & 18 & 6.72 \\
Belgium & 14 & 6.70 \\
Germany & 6 & 6.66 \\
Greece & 5 & 6.60 \\
Spain & 8 & 6.25 \\
Portugal & 9 & 6.25 \\
Saudi Arabia & 4 & 6.25 \\
United Kingdom & 29 & 6.20 \\
Hong Kong & 6 & 6.16 \\
Canada & 9 & 6.11 \\
The Netherlands & 10 & 6.10 \\
France & 15 & 6.00 \\
Japan & 4 & 5.50 \\
Switzerland & 4 & 4.75 \\
\hline Mean for all markets & 216 & 6.47
\end{tabular}

\section{Analysis}

This research sought to test the null hypothesis that given a particular market environment, and a particular set of company characteristics, no foreign market entry technique is more successful than any other. The alternative hypothesis is that given a particular market 
environment, and a particular set of company characteristics, there is a foreign market entry technique that is most likely to succeed. Statistical tests were conducted using analysis of variance and chi square tests based on cross tabulations of the data.

Statistical evidence suggests that there is at best, only a weak relationship between choice of entry technique and success in entering foreign markets (significance level .16). Further analysis suggests that the formation of a new subsidiary is a potentially more successful entry technique than any other tested. But, this evidence is also weak statistically (significance level .15). In addition, interviews revealed that companies are more likely to form new subsidiaries only when the risk of failure is low. Consequently, this entry technique should result in higher success because it is used when the changes for success are greatest.

Company characteristics such as size, experience in entering foreign markets as evidenced by percent of foreign premium, and ownership by a third company were found to be statistically unrelated to success in entering foreign markets. Likewise, market characteristics such as industry profitability based on combined ratio, industry expense ratio and market growth rate were statistically unrelated to success in entering foreign markets.

Two company characteristics, management control of foreign subsidiaries and motivation for entering foreign markets, had statistically significant relationships to success in entering a foreign market (significance level .001 and .0260 respectively). Specifically, those companies that were motivated to enter foreign markets because they followed multinational clients were shown to be more successful than those motivated by any other reason. Concerning management control, those firms that negotiate the goals and objectives for the next planning period with their foreign affiliates appear to be more successful than firms that use other management techniques.

Based upon the statistical analysis of the questionnaire data and upon the evidence gathered through interviews, it is necessary to conclude that the null hypothesis, (given a particular market environment, and a particular set of company characteristics, no foreign market entry technique is more successful than any other), must be accepted. The research did indicate that two company characteristics, motivation for foreign market entry and management control of foreign affiliates were related to success in entering foreign markets.

\section{Conclusion}

The literature of international business indicates that the choice of entry technique by the multinational firm plays an important part in the success the firm enjoys in entering foreign markets $[2,11,15]$. Theories concerned with mode of entry are now emerging in the literature [18]. If scholars are to develop an overall theory of the multinational firm, decisions relating to choice of entry technique must be incorporated in that theory.

Although the theories presented in the literature include multinational service firms, such as insurance, there has been little empirical work done to determine if these theories do, in fact, explain the international activities of service firms [1]. Those scholars that have investigated market entry activities of service firms have done so with a broad brush. That is, they have examined the dichotomy of the services as opposed to other industries. Little work has been done to study international activities of specific types of firms within the services industry such as insurance. 
The academic literature concerned with international insurance has, to date, focused largely on the development of risk theory with universal application and on governmental barriers to trade in insurance [3]. The literature concerning barriers to trade makes an important contribution to understanding mode of entry, in that it shows how entry techniques may be constrained or dictated by governments and thus, beyond the control of the firm $[8,13,16]$.

In both the international business literature and the international insurance literature, scholars have underlined the need for a base of theory. One of the major difficulties in developing such theories, however, is the lack of imperical data from which to work. Problems frequently cited in international business research include lack of data and/or the incomparability of data. Data regarding international insurance operations suffers from the latter fault. It is indeed difficult to compare insurance company performance data between countries.

This study found that there was a relationship between control over foreign affiliates and succes in entering foreign markets. Other characteristics such as firm size and experience in entering foreign markets, which should give rise to firm specific assets which could then be internalized, were not statistically related to success in entering foreign markets. Market characteristics such as profitability, growth rate and expense of doing business, which could lower transactions costs were also statistically unrelated to success in entering foreign markets.

Thus, the data in this study provide only weak support for transactions cost based theories of foreign market entry. This lack of support does not provide the basis for rejecting these theories, however. Data problems alone may account for this lack of support. Further research will be required in order to test more specifically the constructs of these theories as they apply to international insurance operations.

\section{REFERENCES}

1. ALBAUM, Gerald and PETERSON, Robert A. "Emperical Research in International Marketing: 1976-1982", Journal of International Business Studies (Spring 1983): 161-173.

2. ANDERSON, Erin and GATIGNON, Hubert . "Modes of Entry: A Transaction cost Analysis and Propositions", Journal of International Business Studies (Fall 1986): 1-26.

3. BAR-NIV, Ran and BICKELHAUPT, David L. "Research in International Risk and Insurance: Summary, Synthesis, and Prospects", The Journal of Risk and Insurance (March 1981): 119-134.

4. BICKELHAUPT, David L. and BAR-NIV, Ran. International Insurance: Managing Risk in the World (New York: Insurance Information Institute, 1983).

5. BODDEWYN, J.J., HALRICH, Marsha B. and PERRY, A.C. "Service Multinationals: Conceptualization, Measurement and Theory", Journal of International Business Studies (Fall 1986): 41-57.

6. BUCKLEY, P.J. and MATHEW, A.M. "The Motivation for Recent First Time Direct Investments in Australia by UK Firms", Management International Review No. 1 (1979): 57-69. 
7. BUCKLEY, P.J. and MATHEW, A.M.. "Dimensions of the Market Entry Behavior of Recent U.K. First Time Direct Investors in Australia", Management International Review No. 2 (1980): 35-51.

8. CARTER, Robert and DICKINSON, Gerald. Barriers to Trade in Insurance and Reinsurance a Conference Dossier (Geneva: Association Internationale pour l'Etude de l'Économie de l'Assurance, 1977).

9. DUNNING, J.H. "Toward and Eclectic Theory of International Production", Journal of International Business Studies 11, (Spring/Summer 1980): 9-31.

10. DUNNING, J.H. "Explaining Changing Patterns of International Production: In Defense of the Eclectic Theory", Oxford Bulletin of Economics and Statistics (November 1979): 269-295.

11. GOODNOW, James D. "Developments in International Mode of Entry Analysis", International Marketing Review (Autumn 1985): 17.

12. PARKER, Henry G. "Conducting Property and Casualty Business in the Overseas Market", Proceedings of Symposium on Overseas Insurance Operations (New York: Life Office Management Association, 1975).

13. PFEFFER, Irving. "Problems in International Insurance Markets", Issues in Insurance: Volume II John D. Long, ed. (Malvern, Penn: American Institute for Property and Liability Underwriters, 1978).

14. PORTERMAIN, Neil W. "Property/Casualty Operations in Worldwide Overseas Markets", Proceedings of Symposium on Overseas Insurance Operations (New York: Life Office Management Association, 1975).

15. ROOT, Franklin R. Entry Strategies for International Markets (Lexington Mass.: Lexington Books, 1987).

16. SKIPPER, Harold D. Jr. "Protectionism in the Provision of International Insurance Services", The Journal of Risk and Insurance Vo. LIV, No. 1 (March 1987): 55-85.

17. WILSON, W.M. "Succeeding in the International Market", Best's Review Property / Casualty ed. (November 1981): 47-52.

18. WIND, Yoram and ROBERTSON, Thomas S. "Marketing Strategy: New Directions for Theory and Research", Journal of Marketing, (Spring 1983): 15-31.

19. WIND, Yoram and PERLMUTTER, Howard. "On the Identification of Frontier Issues in International Marketing”, Columbia Journal of World Business (Winter 1977): 131-139. 